\title{
Correlation between the state of periodontal tissues and selected risk factors for periodontitis and myocardial infarction
}

\author{
Renata Górska ${ }^{1, A, C, E, F}$, Elżbieta Dembowska ${ }^{2, B}$, Tomasz P. Konopka ${ }^{3, B}$, \\ Joanna Wysokińska-Miszczuk ${ }^{4, B}$, Małgorzata Pietruska ${ }^{5, C}$, Ewa Ganowicz ${ }^{1, D}$ \\ 1 Department of Periodontology and Oral Diseases, Medical University of Warsaw, Poland \\ ${ }^{2}$ Department of Periodontology, Pomeranian Medical University, Szczecin, Poland \\ ${ }^{3}$ Department of Periodontology, Wroclaw Medical University, Poland \\ ${ }^{4}$ Department of Periodontology, Medical University of Lublin, Poland \\ ${ }^{5}$ Department of Periodontal and Oral Mucosa Diseases, Medical University of Bialystok, Poland \\ A - research concept and design; $B$ - collection and/or assembly of data; $C$ - data analysis and interpretation; \\ $D$ - writing the article; $E$ - critical revision of the article; $F$ - final approval of article
}

\section{Address for correspondence \\ Tomasz Konopka}

E-mail: tomasz.konopka@umed.wroc.pl

\section{Funding sources}

None declared

Conflict of interest

None declared

Received on July 8, 2016

Revised on May 24, 2017

Accepted on June 9,2017

\begin{abstract}
Background. The current level of knowledge indicates a relationship between periodontitis and diabetes and/or cardiovascular diseases (CVD). Periodontitis can be not only a risk factor for these diseases, but also a condition modifying other primary risk factors associated with the occurrence of cardiovascular complications (lipid disorders, arterial hypertension, etc.) or diabetes.
\end{abstract}

Objectives. The aim of the study was an analysis of the correlation between the state of periodontal tissues and selected risk factors for myocardial infarction (MI) in patients after recent myocardial infarction.

Material and methods. The study included 417 patients (92 women, 325 men) hospitalized due to recent MI. The inclusion criteria were Ml history and age below 70 years. The state of periodontal tissues (plaque index, bleeding on probing, pocket depth and clinical attachment loss, (Pl index) and selected risk factors for periodontitis and CVD were recorded.

Results. An analysis of the results showed no statistically significant correlation between the depth, the number, percentage of periodontal pockets and the average clinical attachment level on one hand and BMI on the other hand. Whereas a statistically significant correlation was observed between tobacco smoking and the degree of severity of periodontal diseases measured by the average pocket depth, the number and percentage of pockets above $4 \mathrm{~mm}$ and the average clinical attachment loss, as well as between hypertension and the state of oral hygiene and between diabetes and the number of preserved teeth and the number of pockets above $4 \mathrm{~mm}$.

Conclusions. The degree of severity of periodontal disease can impact hypertension and diabetes, which could potentially influence the occurrence and course of CVD.

Key words: risk factors, periodontitis, cardiovascular diseases

DOI

10.17219/acem/74652

Copyright

Copyright by Author(s)

This is an article distributed under the terms of the

Creative Commons Attribution Non-Commercial License

(http://creativecommons.org/licenses/by-nc-nd/4.0/) 


\section{Introduction}

The current level of knowledge indicates a relationship between periodontal disease and systemic diseases, including diabetes, cardiovascular diseases, stroke, premature birth and low birth weight, as well as Parkinson's disease, Alzheimer's disease and pancreatic cancer. Periodontitis can constitute not only a risk factor for these diseases, but also a condition modifying other primary risk factors associated with the occurrence of cardiovascular complications (lipid disorders, arterial hypertension, etc.) or diabetes. ${ }^{1,2}$

Cardiovascular diseases are the main cause of premature death in most European countries. This situation is closely associated with lifestyle and the influence of risk factors on the occurrence and course of cardiovascular diseases.

Risk factors beyond our control include age, gender, genetic load. Those on which we have an influence include cigarette smoking, arterial hypertension, lipid disorders, diabetes and obesity, bad eating habits, stress.

The results of studies in recent years also suggest that in the future periodontal disease may be considered one of the many risk factors for cardiovascular diseases. ${ }^{3}$

Research has shown that the same risk factors as well as the same pathophysiological processes are the underlying cause for the destabilization of atherosclerotic plaques and the destruction of periodontal tissues. Particular attention should be paid to the interactions that could potentially occur between periodontal diseases and other risk factors, i.e. the concentration of lipoproteins LDH and HDL, or arterial hypertension, due to their joint participation in the induction of oxidative stress in the circulatory system. ${ }^{2,4}$

Oxidative stress, generally coexisting with pathogens associated with periodontal disease, which are often detected in atherosclerotic plaque, accelerates apoptosis, and increases inflammation. This process can initiate the erosion of atherosclerotic plaque and raise its vulnerability to rupture, which is a high risk of thrombosis and acute coronary events. ${ }^{5,6}$

The prevalence of periodontal disease in our civilization and the positive results of periodontal therapy necessitate a deeper examination of the pathogenetic mechanisms linking periodontitis with atherosclerosis and consequently with the resulting cardiovascular diseases. ${ }^{7,8}$

Therefore, the objective of this study was to assess the state of periodontal tissues and to analyze the correlation between the state of periodontal tissues and selected risk factors for myocardial infarction in patients after acute myocardial infarction.

\section{Material and methods}

The study was conducted in the Department of Periodontology and in the Clinic and Department of Cardiology of five medical universities in Poland (Warszawa, Szczecin, Wrocław, Lublin, Białystok) in 2010-2014.
The study included 417 patients hospitalized with recent acute myocardial infarction (MI). The inclusion criteria were MI history and age below 70 years. The patients agreed to participate in the study by signing a declaration approved by the Bioethics Committee in Medical University of Warszawa (opinion: KB-145/2011). Patients diagnosed with cancer, rheumatic disease, autoimmune disease, chronic liver disease, chronic renal disease stages 4 and 5, stroke history and individuals receiving periodontal treatment or systemic antibiotic therapy in the preceding 6 months were excluded from the study.

The study group included 417 patients (92 females, 325 males) aged 25 to 69 years.

\section{Social enquiry and general medical history}

All participants of the study were interviewed, which included a collection of the following data:

- General patient data: first name, family name, gender, date of birth, phone number, place of residence;

- Education, defined as primary, secondary and higher education;

- Socio-economic status, determined on the basis of income per family member per month: < 800 PLN, 800-1500 PLN, > 1500 PLN;

- Cigarette smoking, defined as: current (smoking of 10 or more cigarettes a day continuously for at least 5 years), smoking in the past and never;

- Identification of risk factors for cardiovascular disease: arterial hypertension, diabetes, as well as BMI and WHR.

\section{Physical examination}

Physical measurements were performed in accordance with applicable guidelines. All the study participants were evaluated for:

- Weight $[\mathrm{kg}]$, height $[\mathrm{cm}]$, waist circumference $[\mathrm{cm}]$ and hip circumference $[\mathrm{cm}]$, which allowed for the calculation of each patient's body mass index (BMI was calculated by dividing the body weight $[\mathrm{kg}]$ by the square of the body height $\left[\mathrm{m}^{2}\right]$ ) and WHR (WHR was calculated by dividing the waist circumference by the hip circumference). BMI $25-29.9 \mathrm{~kg} / \mathrm{m}^{2}$ was defined as overweight, and BMI $\geq 30 \mathrm{~kg} / \mathrm{m}^{2}$ was defined as obesity. Abdominal obesity was diagnosed when waist circumference (WC) was $\geq 80 \mathrm{~cm}$ in women and $\geq 94 \mathrm{~cm}$ in men.

- Blood pressure, which was measured in a sitting position after several minutes' rest, using a sphygmomanometer. Arterial hypertension was defined as systolic blood pressure $\geq 140 \mathrm{~mm} \mathrm{Hg}$ or diastolic blood pressure $\geq 900 \mathrm{~mm} \mathrm{Hg}$ or use of antihypertensive drugs.

\section{Dental and periodontal examination}

The dental examination took place within 6 weeks after the myocardial infarction. This examination was carried out in an artificial light, using a dental mirror and a peri- 
odontal probe (Hu-Friedy PCPUNC 15). The number of teeth, the number of roots with pulp necrosis present in the mouth and edentulousness rate were determined. The examination did not include third molars. The periodontal examination covered:

- Dichotomous Plaque Index (PI) by O'Leary ${ }^{9}$ on 4 surfaces of the tooth (mesial, distal, lingual and buccal); the presence or absence of plaque was determined;

- Bleeding on Probing (BoP) index by Ainamo and Bay ${ }^{10}$ where the examination was conducted at 4 sites around the tooth: mesial buccal (MB), buccal (B), distal buccal (DB) and lingual (L), only the presence or absence of bleeding from gingiva while probing the pocket was determined;

- Pocket depth (PD) at 4 sites around the tooth: MB, B, DB, $\mathrm{L}$, which was defined as the distance from the gingival margin to the bottom of the pocket determined by the probe;

- The number of active (bleeding) pockets above $4 \mathrm{~mm}$ in depth;

- Clinical attachment loss (CAL) at 4 sites around the tooth: $\mathrm{MB}, \mathrm{B}, \mathrm{DB}, \mathrm{L}$, which is defined as the distance between the bottom of the pocket determined by the probe and the cemento-enamel junction.

The periodontal status of each patient was determined on the basis of the CPI index definition ${ }^{11}$, with the following categories:

- CPI-0 - no inflammatory symptoms,

- CPI-1 - presence of bleeding on probing,

- CPI-2 - presence of supra- and/or subgingival calculus or filling overhangs,

- CPI-3 - presence of pathological periodontal pockets from 3.5 to $5.5 \mathrm{~mm}$ deep,

- CPI-4 - the presence of pathological periodontal pockets $5.5 \mathrm{~mm}$ and deeper.

\section{Statistical analysis}

Statistical analysis was performed using PQStat v. 1.4.4 software. The Mann-Whitney and Kruskal-Wallis tests were used to assess the significance of differences between 2 and more groups. The $\chi^{2}$ test was used to search significant differences between the frequencies of the analyzed data. Correlation between variables were measured by the Spearman rank correlation. P-value lower than 0.05 was decided as significant differences.

\section{Results}

\section{Characteristics of the study group}

The age of patients ranged from 25 to 69 years, with the median at 57 years, and with significantly more men than women (77.9\% vs $22.1 \%)$.

Most of the patients came from large cities (223 individuals, $56.9 \%)$, the least - 69 patients (17.6\%) - lived in the country outside urban areas.
Within the study group the largest subgroup were individuals with a secondary education $53.9 \%$, the least numerous - with incomplete university education or full university education (15.7\%).

Analyzing the income per family member it was observed that more than half had an income ranging from 800 to 1500 PLN per family member (Table 1).

The results of the periodontal examination showed an average of 12 preserved teeth in women and 18 in men (total median: 16 preserved teeth). Mean values of plaque index (PI) were high in both females and males $(76.9 \%$ and $78.2 \%$ respectively). Also the BOP index was high, regardless of gender (44.6\%). The number of pockets $>4 \mathrm{~mm}$ was significantly higher in men (Table 2 ).

\section{Characteristic of risk factors and correlations between variables}

Analyzing risk factors for heart diseases, overweight (BMI $25-30 \mathrm{~kg} / \mathrm{m}^{2}$ ) or obesity $\left(\mathrm{BMI} \geq 30 \mathrm{~kg} / \mathrm{m}^{2}\right.$ ) were observed in almost $80 \%$ of patients. Most of the patients were current or past smokers of tobacco (almost $80 \%$ ), arterial hypertension was present in $90.1 \%$ of individuals in the study group, diabetes in almost $25 \%$, dyslipidemia in more than half of the patients with myocardial infarction (Table 3).

\begin{tabular}{|c|c|c|}
\hline \multicolumn{2}{|c|}{ Patients' overall profiles } & Total \\
\hline \multicolumn{2}{|l|}{ Number of patients } & 417 \\
\hline \multicolumn{2}{|c|}{ Percentage of the study group } & $100.0 \%$ \\
\hline Age & median Q1-Q3 range & $\begin{array}{r}57 \\
52-61.25 \\
25-69\end{array}$ \\
\hline \multicolumn{2}{|c|}{ Number and percentage of females } & $\begin{array}{r}92 \\
22.1 \%\end{array}$ \\
\hline \multirow{3}{*}{ Plece of residence } & city & $\begin{array}{r}223 \\
56.9 \%\end{array}$ \\
\hline & town & $\begin{array}{r}100 \\
25.5 \%\end{array}$ \\
\hline & village & $\begin{array}{r}69 \\
17.6 \% \\
\end{array}$ \\
\hline \multirow{4}{*}{ Education } & primary & $\begin{array}{r}122 \\
30.4 \%\end{array}$ \\
\hline & secondary & $\begin{array}{r}216 \\
53.9 \%\end{array}$ \\
\hline & licentiate & $\begin{array}{r}10 \\
2.5 \%\end{array}$ \\
\hline & Master's degree & $\begin{array}{r}53 \\
13.2 \%\end{array}$ \\
\hline \multirow{3}{*}{ Income per month } & $\begin{array}{l}<800 \text { PLN } \\
\text { per person }\end{array}$ & $\begin{array}{r}101 \\
25.5 \%\end{array}$ \\
\hline & $\begin{array}{l}{[800 ; 1500] \text { PLN }} \\
\text { per person }\end{array}$ & $\begin{array}{r}212 \\
53.5 \%\end{array}$ \\
\hline & $\begin{array}{l}>1500 \text { PLN } \\
\text { per person }\end{array}$ & $\begin{array}{r}83 \\
21.0 \%\end{array}$ \\
\hline
\end{tabular}


Table 2. Full-mouth dental and periodontal status

\begin{tabular}{|c|c|c|c|c|c|}
\hline \multicolumn{2}{|c|}{ Periodontal parameters } & $\begin{array}{l}\text { Females } \\
(\mathrm{n}=92)\end{array}$ & $\begin{array}{l}\text { Males } \\
(n=325)\end{array}$ & $\begin{array}{l}\text { Comparison } \\
\text { (Mann-Whitney test) }\end{array}$ & Total \\
\hline \multicolumn{2}{|c|}{ Number of teeth (median; Q1-Q3) } & $12(4-18)$ & $18(9-23)$ & $p=0.0007$ & $16(8-22)$ \\
\hline \multicolumn{2}{|c|}{ Number of lost teeth (median; Q1-Q3) } & $16(10-24)$ & $10(5-19)$ & $p=0.0007$ & $12(6-20)$ \\
\hline \multicolumn{2}{|c|}{ Number and percentage of edentulous patients } & $15(16.3 \%)$ & $30(9.2 \%)$ & $p=0.0007$ & $4510.8 \%$ \\
\hline \multirow{8}{*}{$\begin{array}{l}\text { Applies only to } \\
\text { patients with } \\
\text { preserved own } \\
\text { teeth }(n=372)\end{array}$} & PI (mean (SD)) & $76.9 \%(25.4)$ & $78.2 \%(21.4)$ & $p=0.8178$ & $77.9 \%(22.3)$ \\
\hline & BOP (mean (SD)) & $45.0 \%(30.8)$ & $44.5 \%(28.6)$ & $p=0.8917$ & $44.6 \%(29.0)$ \\
\hline & PD (mean (SD)) & $2.8(1.3)$ & $2.8(1.0)$ & $p=0.6169$ & $2.8(1.1)$ \\
\hline & $\begin{array}{l}\text { number and percentage of } \\
\text { patients with pockets } \geq 4 \mathrm{~mm}^{*}\end{array}$ & $67(87.0 \%)$ & $270(92.8 \%)$ & $p=0.1050$ & $337(91.6 \%)$ \\
\hline & $\begin{array}{l}\mathrm{PD} \geq 4 \mathrm{~mm}-\text { number } \\
\text { (median; Q1-Q3) }\end{array}$ & $6(2-15)$ & $11(5-21.75)$ & $p=0.0041$ & $10(4-20)$ \\
\hline & $\begin{array}{l}\mathrm{PD} \geq 4 \mathrm{~mm} \text { - percentage } \\
(\text { mean }(\mathrm{SD}))\end{array}$ & $24.8 \%(25.1)$ & $27.4 \%(24.6)$ & $p=0.2508$ & $26.8 \%(24.7)$ \\
\hline & $\mathrm{CAL}$ (mean (SD)) & $3.9(2.0)$ & $3.9(2.2)$ & $p=0.8814$ & $3.9(2.1)$ \\
\hline & CPI (median; Q1-Q3) & $3(3-4)$ & $4(3-4)$ & $p=0.0511$ & $4(3-4)$ \\
\hline
\end{tabular}

Table 3. Values medical risk factors for periodontitis

\begin{tabular}{|c|c|c|}
\hline Risc factors & Subgroups & Values \\
\hline \multirow{5}{*}{$\mathrm{BMI}$} & mean (SD) & $28.7(4.9)$ \\
\hline & $\begin{array}{l}\text { underweight and emaciation (BMI } \\
<18.5 \text { ) }\end{array}$ & $4(1.0 \%)$ \\
\hline & optimal weight & $83(20.1 \%)$ \\
\hline & $\begin{array}{l}\text { overweight } \\
\left(25 \leq \mathrm{BMI}<30 \mathrm{~kg} / \mathrm{m}^{2}\right)\end{array}$ & $179(43.3 \%)$ \\
\hline & obesity (BMI $\geq 30 \mathrm{~kg} / \mathrm{m}^{2}$ ) & $147(35.6 \%)$ \\
\hline \multicolumn{2}{|c|}{ WHR (mean (SD) } & $0.98(0.10)$ \\
\hline \multirow{3}{*}{$\begin{array}{l}\text { Tobacco } \\
\text { smoking }\end{array}$} & presently & $204(49.3 \%)$ \\
\hline & in the past & $115(27.8 \%)$ \\
\hline & never & 95 (22.9\%) \\
\hline \multicolumn{2}{|c|}{ Arterial hypertension } & $309(90.1 \%)$ \\
\hline \multicolumn{2}{|l|}{ Diabetes } & $100(24.2 \%)$ \\
\hline
\end{tabular}

An analysis of the relationship between periodontal status and sociological parameters demonstrated a statistically significant correlation between the number of lost teeth, and age, gender, education and income, a similar association was observed between CPI median and education and income of patients.
An inverse correlation between BOP and PI on one hand and education and income on the other hand was also observed (Table 4).

The conducted study showed a correlation between age, place of residence, education and income on one hand and average pocket depth, number and percentage of pockets above $4 \mathrm{~mm}$ and mean CAL on the other one (Table 5).

No correlation was observed between BMI and activity and severity of periodontitis or the state of oral hygiene and CPI median.

The number of lost teeth, BOP and CPI correlated with smoking. The number of lost teeth and the plaque index showed a statistically significant positive correlation with the cumulative effects of tobacco and its combustion products in the form of the number of pack-years (Table 6).

An analysis of the results showed no relationship between the depth, number and percentage of periodontal pockets and the clinical attachment level on one hand and BMI on the other hand, whereas a certain correlation was observed between tobacco smoking on one hand and the average depth of pockets, the number and percentage pockets $>4 \mathrm{~mm}$ and the average clinical attachment loss on the other hand.

Own research also shows that a great majority, 97\% of individuals with heart attack history, are past or present cigarette smokers. Actually smokers had significantly deeper periodontal pockets and clinical attachment loss. There was significant correlation between CAL and body weight measured only by WHR (Table 7).

The number of teeth in patients with diabetes was significantly lower than among non-diabetic group (Table 8). 
Table 4. Relations between sociodemographic variables and periodontal status (number of teeth, PI, BoP and CPI indices)

\begin{tabular}{|c|c|c|c|c|c|}
\hline \multicolumn{2}{|c|}{$\begin{array}{c}\text { Median }(\mathrm{Q} 1 ; \mathrm{Q} 3) \\
\text { Mean } \pm \text { SD }\end{array}$} & Number of teeth & $\mathrm{PI}$ & $\mathrm{BOP}$ & CPI median \\
\hline \multicolumn{2}{|c|}{ Age (Spearman's rank correlation test) } & $\begin{array}{c}r=0.37 \\
p<0.0001\end{array}$ & $\begin{array}{c}r=0.07 \\
p=0.1763\end{array}$ & $\begin{array}{c}r=0.02 \\
p=0.6986\end{array}$ & $\begin{array}{c}r=0.07 \\
p=0.1707\end{array}$ \\
\hline \multirow{2}{*}{ Gender } & females & $16(10 ; 24)$ & $76.9 \% \pm 25.4$ p.p. & $45.0 \% \pm 30.8$ p.p. & $3(2 ; 3)$ \\
\hline & males & $10(5 ; 19)$ & $77.6 \% \pm 22.2$ p.p. & $44.2 \% \pm 28.6$ p.p. & $3(2 ; 4)$ \\
\hline \multicolumn{2}{|l|}{ Mann-Whitney U test } & $p=0.0007$ & $p=0.7310$ & $p=0.9595$ & $p=0.5283$ \\
\hline \multirow{3}{*}{ Place of residence } & city & $11(5 ; 20)$ & $78.3 \% \pm 21.6$ p.p. & $43.7 \% \pm 29.1$ p.p. & $3(2 ; 4)$ \\
\hline & town & $15(8 ; 23)$ & $77.5 \% \pm 22.4$ p.p. & $49.4 \% \pm 28.9$ р.р. & $3(2 ; 4)$ \\
\hline & village & $11(6 ; 17)$ & $83.0 \% \pm 18.8$ p.p. & $49.1 \% \pm 28.5$ p.p. & $3(3 ; 3)$ \\
\hline \multicolumn{2}{|c|}{ Spearman's rank correlation test } & $\begin{array}{c}r=0.04 \\
p=0.4125\end{array}$ & $\begin{array}{c}r=0.06 \\
p=0.2705\end{array}$ & $\begin{array}{c}r=0.10 \\
p=0.0677\end{array}$ & $\begin{array}{c}r=0.05 \\
p=0.3254\end{array}$ \\
\hline \multirow{4}{*}{ Education } & primary & $16(9 ; 23)$ & $86.8 \% \pm 17.8$ p.p. & $57.1 \% \pm 29.5$ p.p. & $3(3 ; 4)$ \\
\hline & secondary & $12(6 ; 20)$ & $77.6 \% \pm 21.0$ p.p. & $42.7 \% \pm 27.4$ p.p. & $3(2 ; 4)$ \\
\hline & BA & $10(8 ; 12)$ & $41.1 \% \pm 28.1$ p.p. & $26.0 \% \pm 22.8$ p.p. & $2(1 ; 3)$ \\
\hline & MA & $6(3 ; 14)$ & $70.2 \% \pm 21.6$ p.p. & $36.3 \% \pm 27.7$ p.p. & $2.5(2 ; 3)$ \\
\hline \multicolumn{2}{|c|}{ Spearman's rank correlation test } & $\begin{array}{l}r=-0.26 \\
p<0.0001\end{array}$ & $\begin{array}{c}r=-0.31 \\
p<0.0001\end{array}$ & $\begin{array}{l}r=-0.28 \\
p<0.0001\end{array}$ & $\begin{array}{l}r=-0.26 \\
p<0.0001\end{array}$ \\
\hline \multirow{3}{*}{ Income per month } & $<800$ PLN per person & $15(9 ; 23)$ & $87.4 \% \pm 17.5$ p.p. & $56.2 \% \pm 29.1$ p.p. & $3(3 ; 4)$ \\
\hline & $\begin{array}{l}{[800 ; 1500] \text { PLN }} \\
\text { per person }\end{array}$ & $12(8 ; 21)$ & 77.9\% 土 21.1 p.p. & $44.6 \% \pm 28.2$ p.p. & $3(2 ; 4)$ \\
\hline & > 1500 PLN per person & $6(3 ; 12)$ & $71.2 \% \pm 22.9$ p.p. & $37.4 \% \pm 27.4$ p.p. & $3(2 ; 3)$ \\
\hline \multicolumn{2}{|c|}{ Spearman's rank correlation test } & $\begin{array}{l}r=-0.30 \\
p<0.0001\end{array}$ & $\begin{array}{l}r=-0.27 \\
p<0.0001\end{array}$ & $\begin{array}{l}r=-0.24 \\
p<0.0001\end{array}$ & $\begin{array}{l}r=-0.22 \\
p<0.0001\end{array}$ \\
\hline
\end{tabular}

\section{Discussion}

Age and gender are an important, non-modifiable risk factor for both periodontal disease and cardiovascular disease. Numerous epidemiological studies confirm a higher incidence of periodontitis in the elderly. ${ }^{12,13}$ Studies conducted by Persson et al. ${ }^{14}$ showed that both of these diseases may occur simultaneously, particularly in individuals over 60 years of age. The occurrence of periodontal disease was observed in about $50 \%$ of those aged over 60 years, and $55 \%$ were overweight or with an episode of stroke or acute coronary syndrome. ${ }^{14}$

Our study also showed a higher incidence of myocardial infarction, as well as periodontal disease in men. Male predilection for the occurrence of periodontal disease and cardiovascular disease was also observed by other authors. ${ }^{13,15,16}$

An analysis of modifiable factors, which depend on us, included, among other things, education and the degree of wealth. Our study showed a lower number of individuals with higher education and higher income among patients after myocardial infarction. Zhang et al. ${ }^{17}$ demonstrated that education lasting at least 6 years significantly affects the decreased incidence of advanced periodontal disease and impacts the course of treatment and survival of patients after ACS.

Individuals with higher education usually have a permanent job, which is associated with a regular income and frequent access to dental care. They also have higher health awareness.

Our results are also confirmed by other authors, indicating that the level of wealth is an important modifiable risk factor for periodontal disease. ${ }^{13}$ These results can also indicate that individuals with a low income lose their own teeth earlier, due to the limited possibility of receiving treatment. These results also showed a high proportion of toothlessness, which occurred earlier in individuals with a lower income after myocardial infarction. ${ }^{12,18}$ 
Table 5. Relations between sociodemographic variables and periodontal status (PD, CAL)

\begin{tabular}{|c|c|c|c|c|c|}
\hline \multicolumn{2}{|c|}{$\begin{array}{c}\text { Median (Q1; Q3) } \\
\text { Mean } \pm \text { SD }\end{array}$} & Mean PD & $\mathrm{PD} \geq 4 \mathrm{~mm}$ - number & $\begin{array}{l}\mathrm{PD} \geq 4 \mathrm{~mm} \\
\text { - percentage }\end{array}$ & Mean CAL \\
\hline \multicolumn{2}{|c|}{ Age (Spearman's rank correlation test) } & $\begin{array}{c}r=0.10 \\
p=0.0677\end{array}$ & $\begin{array}{c}r=-0.03 \\
p=0.5966\end{array}$ & $\begin{array}{c}r=0.11 \\
p=0.0283\end{array}$ & $\begin{array}{c}r=0.18 \\
p=0.0007\end{array}$ \\
\hline \multirow{2}{*}{ Gender } & females & $2.8 \pm 1.3$ & $6(2 ; 15)$ & $24.8 \% \pm 25.1$ p.p. & $3.9 \pm 2.0$ \\
\hline & males & $2.8 \pm 1.0$ & $11(5 ; 22)$ & $27.3 \% \pm 24.6$ p.p. & $3.9 \pm 2.2$ \\
\hline \multicolumn{2}{|c|}{ Mann-Whitney $U$ test } & $p=0.6146$ & $p=0.0039$ & $p=0.2599$ & $p=0.8270$ \\
\hline \multirow{3}{*}{ Place of residence } & city & $2.7 \pm 0.9$ & $9(3 ; 21)$ & $25.2 \% \pm 23.5$ p.p. & $3.8 \pm 2.1$ \\
\hline & town & $3.1 \pm 1.1$ & $9(5 ; 16)$ & $31.3 \% \pm 28.8$ p.p. & $4.6 \pm 2.1$ \\
\hline & village & $3.1 \pm 1.4$ & $11(6 ; 22)$ & $28.4 \% \pm 24.1$ p.p. & $4.0 \pm 2.0$ \\
\hline \multicolumn{2}{|c|}{ Spearman's rank correlation test } & $\begin{array}{c}r=0.13 \\
p=0.0184\end{array}$ & $\begin{array}{c}r=0.07 \\
p=0.2099\end{array}$ & $\begin{array}{c}r=0.09 \\
p=0.0937\end{array}$ & $\begin{array}{c}r=0.09 \\
p=0.0859\end{array}$ \\
\hline \multirow{4}{*}{ Education } & primary & $3.1 \pm 1.0$ & $11(6 ; 24)$ & $33.6 \% \pm 26.3$ p.p. & $4.6 \pm 2.2$ \\
\hline & secondary & $2.9 \pm 1.1$ & $10(4 ; 20)$ & $26.5 \% \pm 23.9$ p.p. & $3.9 \pm 2.0$ \\
\hline & BA & $2.2 \pm 0.6$ & $3.5(1 ; 9.5)$ & $8.8 \% \pm 9.7$ p.p. & $1.6 \pm 1.4$ \\
\hline & MA & $2.5 \pm 0.9$ & $6(2 ; 16)$ & $19.2 \% \pm 23.9$ p.p. & $3.3 \pm 1.8$ \\
\hline \multicolumn{2}{|c|}{ Spearman's rank correlation test } & $\begin{array}{c}r=-0.23 \\
p<0.0001\end{array}$ & $\begin{array}{c}r=-0.16 \\
p=0.0031\end{array}$ & $\begin{array}{c}r=-0.24 \\
p<0.0001\end{array}$ & $\begin{array}{c}r=-0.26 \\
p<0.0001\end{array}$ \\
\hline \multirow{3}{*}{ Income per month } & $<800$ PLN per person & $3.1 \pm 1.1$ & $10.5(5 ; 23)$ & $33.0 \% \pm 26.4$ p.p. & $4.5 \pm 2.2$ \\
\hline & $\begin{array}{l}{[800 ; 1500] \text { PLN }} \\
\text { per person }\end{array}$ & $2.9 \pm 1.2$ & $10(5 ; 19)$ & $28.4 \% \pm 25.6$ p.p & $4.2 \pm 2.1$ \\
\hline & > 1500 PLN per person & $2.4 \pm 0.7$ & $8(2 ; 18.5)$ & $18.0 \% \pm 19.0$ p.p. & $2.9 \pm 1.7$ \\
\hline \multicolumn{2}{|c|}{ Spearman's rank correlation test } & $\begin{array}{l}r=-0.22 \\
p<0.0001\end{array}$ & $\begin{array}{l}r=-0.07 \\
p=0.1661\end{array}$ & $\begin{array}{c}r=-0.21 \\
p=0.0001\end{array}$ & $\begin{array}{c}r=-0.24 \\
p<0.0001\end{array}$ \\
\hline
\end{tabular}

Studies by Bertoldi et al. ${ }^{15}$ indicated that a higher income correlated with a lower number of lost teeth, but also with a better condition of periodontal tissues. People with a lower socio-economic status had fewer teeth, most likely due to the fact that tooth extractions are less expensive and less time consuming, and persons with higher status had more teeth, perhaps because they more often opted for conservative treatment.

Analyzing the group of patients after myocardial infarction, it clear that the number of preserved teeth and the condition of periodontal tissues is much worse compared to epidemiological studies on randomly selected Poles of the same age group. ${ }^{13}$ Indeed, the average number of preserved teeth in the group after myocardial infarction was 12 in women and 18 in men (mean 16).

Studies by Górski et al. ${ }^{19}$ showed an average of 24 teeth in the control group of the same age. In the group of patients after myocardial infarction also the percentage of edentulous individuals was high at $16.3 \%$ in women and $9.2 \%$ in men (mean 10.8\%), in the control group examined by the above-mentioned author the number of edentulous patients was $2.5 \%$.

A research by Desvarieux et $\mathrm{al}^{20}$ on the relation between the number of teeth and progression of atherosclerosis and risk of myocardial infarction showed plaque in carotid arteries in $46 \%$ of individuals who had lost from 0 to 9 teeth and in $60 \%$ of individuals who had lost more than 10 teeth. Also studies by Schillinger et al. ${ }^{21}$ indicated that toothless patients had more advanced atherosclerotic lesions in carotid arteries.

Holmlund et al. ${ }^{22}$ reported that individuals with more than 10 teeth demonstrated a 7-fold increase in the risk of mortality from heart attacks compared to persons with more than 25 teeth, as well as more advanced atherosclerotic lesions in carotid arteries in individuals with fewer teeth. 
Table 6. Relations between general health parameters and periodontal status (number of teeth, PI, BoP and CPI indices)

\begin{tabular}{|c|c|c|c|c|c|}
\hline \multicolumn{2}{|c|}{$\begin{array}{l}\text { Median }(\mathrm{Q} 1 ; \mathrm{Q} 3) \\
\quad \text { Mean } \pm \mathrm{SD}\end{array}$} & Number of teeth & $\mathrm{PI}$ & $\mathrm{BOP}$ & CPI median \\
\hline \multirow{4}{*}{ BMI } & $\begin{array}{l}\text { underweight and } \\
\text { emaciation } \\
(\mathrm{BMI}<18.5)\end{array}$ & $11(3 ; 18)$ & $72.0 \% \pm 33.1$ p.p. & $37.7 \% \pm 33.0$ p.p. & $3(2 ; 4)$ \\
\hline & optimal weight & $14(8 ; 21)$ & $78.4 \% \pm 24.0$ p.p. & $46.9 \% \pm 32.3$ p.p. & $3(2 ; 3)$ \\
\hline & $\begin{array}{l}\text { overweight } \\
\left(25 \leq \mathrm{BMl}<30 \mathrm{~kg} / \mathrm{m}^{2}\right)\end{array}$ & $10(5 ; 19)$ & $75.6 \% \pm 23.7$ p.p. & $41.8 \% \pm 28.7$ p.p. & $3(2 ; 4)$ \\
\hline & $\begin{array}{l}\text { obesity } \\
\left(\mathrm{BMl} \geq 30 \mathrm{~kg} / \mathrm{m}^{2}\right)\end{array}$ & $11(7 ; 20)$ & $79.1 \% \pm 21.0$ p.p. & $46.5 \% \pm 27.6$ p.p. & $3(3 ; 4)$ \\
\hline \multicolumn{2}{|c|}{ Spearman's rank correlation test } & $\begin{array}{l}r=-0.03 \\
p=0.6007\end{array}$ & $\begin{array}{c}r=0.02 \\
p=0.7601\end{array}$ & $\begin{array}{l}r=0.06 \\
p=0.2171\end{array}$ & $\begin{array}{c}r=0.07 \\
p=0.1961\end{array}$ \\
\hline \multicolumn{2}{|c|}{ WHR (Spearman's rank correlation test) } & $\begin{array}{c}r=0.05 \\
p=0.3231\end{array}$ & $\begin{array}{l}r=-0.01 \\
p=0.8888\end{array}$ & $\begin{array}{l}r=0.02 \\
p=0.7217\end{array}$ & $\begin{array}{c}r=0.10 \\
p=0.0827\end{array}$ \\
\hline \multirow{3}{*}{ Tobacco smoking } & presently & $14(7 ; 21)$ & $80.4 \% \pm 20.5$ p.p. & $48.0 \% \pm 28.7$ p.p. & $3(3 ; 4)$ \\
\hline & in the past & $11(5 ; 20)$ & $74.1 \% \pm 23.4$ p.p. & $41.1 \% \pm 29.1$ p.p. & $3(2 ; 3)$ \\
\hline & never & $10(5 ; 17)$ & $75.1 \% \pm 26.0$ p.p. & $40.6 \% \pm 28.6$ p.p. & $3(2 ; 4)$ \\
\hline \multicolumn{2}{|c|}{ Kruskal-Wallis ANOVA } & $p=0.0138$ & $p=0.0583$ & $p=0.0350$ & $p<0.0001$ \\
\hline \multicolumn{2}{|c|}{$\begin{array}{l}\text { Number of pack-years } \\
\text { (Spearman's rank correlation test) }\end{array}$} & $\begin{array}{c}r=0.29 \\
p<0.0001\end{array}$ & $\begin{array}{c}r=0.18 \\
p=0.0196\end{array}$ & $\begin{array}{c}r=0.02 \\
p=0.7817\end{array}$ & $\begin{array}{c}r=0.13 \\
p=0.0972\end{array}$ \\
\hline
\end{tabular}

The state of periodontal tissues evaluated by the number and percentage of patients with pockets above $4 \mathrm{~mm}$ and the average CAL was higher compared to the control group in the study by Górski et al. ${ }^{19}$, respectively 14.3 vs 8.5 and 4.2 vs 2.5 .

Our study showed no correlation between BMI and the average pocket depth, the number and percentage of pockets above $4 \mathrm{~mm}$, or the average clinical attachment loss. However, a statistically significant correlation was observed between WHR and the number of pockets above $4 \mathrm{~mm}$ and the average CAL. The BMI data is not a confirmed association between obesity and periodontitis by other authors. ${ }^{23,24} \mathrm{Al}-$ Zahrani et al. ${ }^{25}$ showed that there is an association between high BMI and WHR on the one hand and an increase of typical periodontal disease indicators: CAL, PD and BOP. Similar observations were made by Dalla Vecchia et al. ${ }^{6}$, who evaluated the association between overweight, obesity and periodontitis. The meta-analysis of Chaffee and Weston ${ }^{26}$ demonstrated a stronger obesity- periodontitis association in younger persons, women and non-smokers than in the general population.

In our study we observed a correlation between smoking and average pocket depth, the number and percentage pockets above $4 \mathrm{~mm}$ and an average loss of clinical attachment loss. The study also shows that most people who experienced a heart attack were past or present cigarette smokers. Hyman et al. ${ }^{27}$ demonstrated that smokers with concomitant advanced periodontitis were at 8-fold higher risk of myocardial infarction. Tobacco smoking is undoubtedly the most important risk factor for both cardiovascular $^{28}$ and periodontitis. Studies have shown that in the case of death of a smoker before 50 years of age due to CVD, there is a $80 \%$ probability that this death was caused by the addiction. ${ }^{29}$ Results obtained by other authors ${ }^{16,30}$ confirm our data.

Another modifiable risk factor for both diseases is diabetes. Our own study shows that $25 \%$ of patients after myocardial infarction also suffered from coexisting diabetes. Wożakowska-Kapłon et al. ${ }^{31}$ observed diabetes in $34 \%$ of MI patients younger than 60 years old. The risk of periodontitis progression in patients with poorly controlled diabetes is 11 times higher than in healthy control. $^{32}$ Studies by Kannel et al. ${ }^{33}$ and McGee et al. ${ }^{34}$ showed that diabetes increases the risk of fatal cardiovascular complications by 1.7 times in men and 2.1 times in women. The INTERHEART study showed that diabetes increases the risk of myocardial infarction by 3.08 times $^{35}$ and of mortality in patients with acute coronary syndrome. ${ }^{36}$ On the other hand, studies by Gerstein et al. ${ }^{37}$ indicated that the risk of MI rises with values of $\mathrm{HbA} 1 \mathrm{C}$ $>5.4 \%$, and any growth in hemoglobin concentration by one percentage point independently increases the risk of MI by additional $19 \%$.

In our study group, more than $90 \%$ of patients with myocardial infarction had arterial hypertension, which is 
a very important risk factor for cardiovascular disease, and recent studies increasingly indicate a relationship between the state of marginal periodontal tissues and blood pressure values. ${ }^{38}$ This correlation appears to result from the outflow of bacteria associated with periodontitis, which may be responsible for the increase in both systolic and diastolic blood pressure through an immune reaction by activating $\mathrm{T}$ lymphocytes. The immune reaction may cause increased sensitivity of the body to the action of angiotensin II. ${ }^{39}$

Table 7. Relations between general health parameters and periodontal status (PD, CAL)

\begin{tabular}{|c|c|c|c|c|c|}
\hline \multicolumn{2}{|c|}{$\begin{array}{l}\text { Median }(\mathrm{Q} 1 ; \mathrm{Q} 3) \\
\text { Mean } \pm \mathrm{SD}\end{array}$} & Mean PD & $\mathrm{PD} \geq 4 \mathrm{~mm}$ - number & $\begin{array}{l}\mathrm{PD} \geq 4 \mathrm{~mm} \\
\text { - percentage }\end{array}$ & Mean CAL \\
\hline \multirow{4}{*}{ BMI } & $\begin{array}{l}\text { underweight and } \\
\text { emaciation } \\
(\mathrm{BMI}<18.5)\end{array}$ & $3.1 \pm 1.5$ & $10(5 ; 18)$ & $34.2 \% \pm 37.9$ p.p. & $4.0 \pm 3.3$ \\
\hline & optimal weight & $2.9 \pm 1.0$ & $9(4 ; 18)$ & $27.9 \% \pm 23.8$ p.p. & $3.9 \pm 2.2$ \\
\hline & $\begin{array}{l}\text { overweight } \\
\left(25 \leq \mathrm{BMI}<30 \mathrm{~kg} / \mathrm{m}^{2}\right)\end{array}$ & $2.8 \pm 1.0$ & $10(3 ; 22)$ & $26.4 \% \pm 25.3$ p.p. & $3.8 \pm 2.2$ \\
\hline & $\begin{array}{l}\text { obesity } \\
\left(\mathrm{BMI} \geq 30 \mathrm{~kg} / \mathrm{m}^{2}\right)\end{array}$ & $2.9 \pm 1.1$ & $10(5 ; 20)$ & $26.6 \% \pm 24.4$ p.p. & $4.0 \pm 2.0$ \\
\hline \multicolumn{2}{|c|}{ Spearman's rank correlation test } & $\begin{array}{c}r=0.02 \\
p=0.6621\end{array}$ & $\begin{array}{c}r=0.06 \\
p=0.2542\end{array}$ & $\begin{array}{c}r=0.02 \\
p=0.7447\end{array}$ & $\begin{array}{c}r=0.06 \\
p=0.2764\end{array}$ \\
\hline \multicolumn{2}{|c|}{ WHR (Spearman's rank correlation test) } & $\begin{array}{c}r=0.07 \\
p=0.2040\end{array}$ & $\begin{array}{c}r=0.11 \\
p=0.0544\end{array}$ & $\begin{array}{c}r=0.09 \\
p=0.1015\end{array}$ & $\begin{array}{c}r=0.13 \\
p=0.0235\end{array}$ \\
\hline \multirow{3}{*}{ Tobacco smoking } & presently & $3.1 \pm 1.2$ & $12(6 ; 22)$ & $32.8 \% \pm 27.0$ p.p. & $4.5 \pm 2.0$ \\
\hline & in the past & $2.6 \pm 0.9$ & $7(2 ; 17)$ & $22.0 \% \pm 22.5$ p.p. & $3.2 \pm 2.2$ \\
\hline & never & $2.6 \pm 0.7$ & $9(3 ; 18)$ & $20.1 \% \pm 19.1$ p.p. & $3.3 \pm 1.9$ \\
\hline \multicolumn{2}{|c|}{ Kruskal-Wallis ANOVA } & $p<0.0001$ & $p=0.0039$ & $p=0.0001$ & $p<0.0001$ \\
\hline \multicolumn{2}{|c|}{$\begin{array}{l}\text { Number of pack-years } \\
\text { (Spearman's rank correlation test) }\end{array}$} & $\begin{array}{c}r=0.07 \\
p=0.3625\end{array}$ & $\begin{array}{c}r=0.12 \\
p=0.1382\end{array}$ & $\begin{array}{c}r=0.13 \\
p=0.0934\end{array}$ & $\begin{array}{c}r=0.13 \\
p=0.0964\end{array}$ \\
\hline \multirow{2}{*}{ Arterialhypertension } & yes & $3.0 \pm 1.1$ & $10(5 ; 20)$ & $29.3 \% \pm 25.4$ p.p. & $4.2 \pm 2.0$ \\
\hline & no & $2.8 \pm 0.9$ & $8(3 ; 21)$ & $23.4 \% \pm 21.9$ p.p. & $4.1 \pm 1.8$ \\
\hline \multicolumn{2}{|l|}{ Mann-Whitney U test } & $p=0.3546$ & $p=0.488$ & $p=0.1985$ & $p=0.5376$ \\
\hline \multirow{2}{*}{ Diabetes } & yes & $2.8 \pm 0.9$ & $7(2 ; 14)$ & $25.2 \% \pm 23.7$ p.p. & $4.3 \pm 2.0$ \\
\hline & no & $2.9 \pm 1.1$ & $11(4 ; 22)$ & $27.4 \% \pm 25.1$ p.p. & $3.8 \pm 2.2$ \\
\hline \multicolumn{2}{|l|}{ Mann-Whitney U test } & $p=0.8718$ & $p=0.0121$ & $p=0.4631$ & $p=0.0904$ \\
\hline
\end{tabular}

Table 8. Differences between periodontal status (number of teeth, PI, BoP and CPI indices) in patients with arterial hypertension and diabetes

\begin{tabular}{|c|c|c|c|c|c|}
\hline \multicolumn{2}{|c|}{$\begin{array}{c}\text { Median }(\mathrm{Q} 1 ; \mathrm{Q} 3) \\
\text { Mean } \pm \mathrm{SD}\end{array}$} & Number of teeth & $\mathrm{PI}$ & BOP & CPI median \\
\hline \multirow{2}{*}{ Arterial hypertension } & yes & $12(7 ; 20)$ & $78.5 \% \pm 22.4$ p.p. & $46.1 \% \pm 28.8$ p.p. & $3(2 ; 4)$ \\
\hline & no & $12(6 ; 17)$ & $86.0 \% \pm 17.9$ p.p. & $50.5 \% \pm 30.5$ p.p. & $3(2 ; 4)$ \\
\hline \multicolumn{2}{|l|}{ Mann-Whitney U test } & $p=0.1527$ & $p=0.0618$ & $p=0.3864$ & $p=0.6304$ \\
\hline \multirow{2}{*}{ Diabetes } & yes & $16(7 ; 22)$ & $79.7 \% \pm 20.5$ p.p. & $46.3 \% \pm 31.6$ p.p. & $3(2 ; 4)$ \\
\hline & no & $11(6 ; 20)$ & $76.5 \% \pm 23.6$ p.p. & $43.3 \% \pm 27.9$ p.p. & $3(2 ; 4)$ \\
\hline \multicolumn{2}{|l|}{ Mann-Whitney U test } & $p=0.0132$ & $p=0.3665$ & $p=0.5923$ & $p=0.844$ \\
\hline
\end{tabular}




\section{Conclusions}

Summing up, it must be said that in the light of modern research the role of risk factors for the occurrence and course of periodontal diseases and cardiovascular diseases is unquestionable, but whether the list of known risk factors for CVD will be supplemented by periodontitis is a matter of time and research.

Our own studies have confirmed that periodontitis and the degree of its severity have an impact on hypertension and diabetes, WHR, which potentially could influence the occurrence of cardiovascular diseases, which could lead to myocardial infarction.

\section{References}

1. Borrell LN, Papapanou PN. Analytical epidemiology of periodontitis. J Clin Periodontol. 2005;32:132-158.

2. Napora M, Ganowicz E, Górska R. Correlation between the state of periodontal tissue and selected cardiovascular parameters in patients with 2 diabetes. Centr Eur J Immunol. 2013;38:556-561.

3. D'Auito F, Sabbah W, Netuveli G, Donos N, Hingorani AD, Deanfield J, Tsakos G. Association of the metabolic syndrome with severe periodontitis in a large U.S. population-based survey. $J$ Clin Endocrinol Metab. 2008;93:3989-3994.

4. Tonetti MS, Van Dyke TE. Periodontitis and atherosclerotic cardiovascular disease: consensus report of the Joint EFP/AAP Workshop on periodontitis and systemic diseases. J Periodontol. 2013;84:(Suppl.4)24-29.

5. Amar S, Gokce N, Morgan S, Loukideli M, Van Dyke TE, Vita JA: Periodontal disease is associated with brachial artery endothelial dysfunction and systemic inflammation. Arterioscler Thromb Vasc Biol. 2003;23:1245-1249.

6. Dalla Vecchia CF, Susin C, Rösing CK, Oppermann RV, Albandar $J M$. Overweight and obesity as risk indicators for periodontitis in adults. J Periodontol. 2005;76:1721-1728.

7. Tonetti MS, Claffey N. Advances in the progression of periodontitis and proposal of definitions of a periodontitis case and disease progression for use in risk factor research. Group $C$ consensus report of the $5^{\text {th }}$ European Workshop in Periodontology. J Clin Periodontol. 2005;32:(Suppl. 6)210-213.

8. Tonetti MS, D'Aiuto F, Nibali L, Donald A, Storry C, Parkar M, Suvan $J$ J Hingorani AD, Vallance P, Deanfield J. Treatment of periodontitis and endothelial function. N Eng/ J Med. 2007;356:911-920.

9. O'Leary TJ, Drake RB, Naylor JE. The plaque control record. J Periodontol. 1972;43:38-46.

10. Ainamo J, Bay I. Problems and proposal for recording gingivitis and plaque. Int Dent J. 1975;25:229-235.

11. Cutress TW, Ainamo J, Sardo-Infirri J. The community periodontal index of treatment needs (CPITN) procedure for population groups and individuals. Int Dent J. 1987;37:222-233.

12. Eke PI, Dye BA, Wei L, Thornton-Evans G, Genco RJ. Prevalence of periodontitis in adults in the United States: 2009 and 2010. J Dent Res. 2012;91:914-920.

13. Konopka T, Dembowska E, Pietruska M, Dymalski P, Górska R: Periodontal status and selected parameters of oral condition of Poles aged from 65 to 74 years. Przegl Epidemiol. 2015;69:643-647.

14. Persson RE, Hollender LG, Powell VL, MacEntee M, Wyatt CC, Kiyak HA, Persson GR. Assessment of periodontal conditions and systemic disease in older subjects. II. Focus on cardiovascular diseases. J Clin Periodontol. 2002;29:803-810.

15. Bertoldi C, Lalla M, Pradelli JM, Cortellini P, Lucchi A, Zaffe D. Risk factors and socioeconomic condition effects on periodontal and dental health: A pilot study among adults over fifty years of age. Eur J Dent. 2013;7:336-346.

16. Thornton-Evans G, Eke P, Wei L, Palmer A, Moeti R, Hutchins S, Borrell $\mathrm{LN}$. Periodontitis among adults aged $>30$ years - United States, 2009-2010. Morb Mort Week Rep. 2013;62:129-134.
17. Zhang Q, Li Z, Wang C, Shen T, Yang Y, Chotivichien S, Wang L. Prevalence and predictors for periodontitis among adults in China, 2010. Glob Health Action 2014;8:24503.

18. D'Aiuto F, Parkar M, Nibali L, Suvan J, Lessem J, Tonetti MS. Periodontal infections cause changes in traditional and novel cardiovascular risk factors: Results from a randomized controlled clinical trial. Am Heart J. 2006;151:977-984.

19. Górski B, Nargiełło E, Opolski G, Ganowicz E, Górska R. Correlation between tooth loss and an increased risk of myocardial infarction in adult Polish population below 70 years of age - a case-control study. Nowa Stomatol. 2016;21:1,30-39.

20. Desvarieux M, Demmer RT, Jacobs Jr DR, Rundek T, Boden-Albala B, Sacco RL, Papapanou PN. Periodontal bacteria and hypertension: The Oral Infections and Vascular Disease Epidemiology Study (INVEST). J Hypertens. 2010;28:1413-1421.

21. Schillinger T, Kluger W, Exner M, Mlekusch W, Sabeti S, Amighi J, Wagner $\mathrm{O}$, Minar E, Schillinger M. Dental and periodontal status and risk for progression of carotid atherosclerosis: The inflammation and carotid artery risk for atherosclerosis study dental substudy. Stroke. 2006;37:2271-2276.

22. Holmlund A, Holm G, Lind L. Severity of periodontal disease and number of remaining teeth are related to the prevalence of myocardial infarction and hypertension in a study based on 4,254 subjects. J Periodontol. 2006;77:1173-1178.

23. Kongstad J, Hvidtfeld UA, Grønbaek M, Stoltze K, Holmstrup P. The relationship between body mass index and periodontitis in the Copenhagen City Heart Study. J Periodontol. 2009;80:1246-1253.

24. Ylöstalo P, Suominen-Taipale L, Reunanen A, Knuuttila M. Association between body weight and periodontal infection. $J$ Clin Periodontol. 2008;35:297-304.

25. Al-Zahrani MS, Bissada NF, Borawskit EA. Obesity and periodontal disease in young, middle-aged, and older adults. J Periodontol. 2003;74:610-615.

26. Chaffee B, Weston SJ. Association between chronic periodontal disease and obesity: A systematic review and meta-analysis. J Periodontol. 2010;81:1708-1724.

27. Hyman JJ, Winn DN, Reid BC. The role of cigarette smoking in the association between periodontal disease and coronary heart disease. J Periodontol. 2002;73:988-994.

28. Teo KK, Ounpuu S, Hawken S, Pandey MR, Valentin V, Hunt D, Diaz $\mathrm{R}$, Rashed W, Freeman R, Jiang L, Zhang X, Yusuf S. INTERHEART Study Investigators: Tobacco use and risk of myocardial infarction in 52 countries in the INTERHEART study: A case-control study. Lancet. 2006;368:647-658.

29. Parish S, Collins R, Peto R, Youngman L, Barton J, Jayne K, Clarke R, Appleby P, Lyon V, Cederholm-Williams S, Marshall J, Sleight P. Cigarette smoking, tar yields, and non-fatal myocardial infarction: 14,000 cases and 32,000 controls in the United Kingdom. The International Studies of Infarct Survival (ISIS) Collaborators. BMJ. 1995;311:471-477.

30. Rudziński R, Banach J, Safranow K, Jakubowska K, Olszewska M, Dembowska E, Drożdzik A, Mazurek-Mochol M, Chlubek D: Nicotine, its major metabolites and selected assessment of exposure to tobacco smoke of patients with chronic periodontitis. Dent Med Probl. 2011;48:355-363 (in Polish).

31. Wożakowska-Kapłon B, Włosowicz M, Gorczyca-Michta I, Górska R. Oral health status and the occurrence and clinical course of myocardial infarction in hospital phase: a case-control study. Cardiol $J$. 2013;20:370-377.

32. Taylor GW, Burt BA, Becker MP, Genco RJ, Shlossman M. Glycemic control and alveolar bone loss progression in type 2 diabetes. Ann Periodontol. 1998;3:30-39.

33. Kannel WB, Dawber TR, Kagan A, Revotskie N, Stokes J. Factors of risk in the development of coronary heart disease- six year follow-up experience. The Framingham Study. Ann Intern Med. 1961;55:33-50.

34. McGee D, Cooper R, Liao Y, Durazo-Arvizu R. Patterns of comorbidity and mortality risk in blacks and whites. Ann Epidemiol. 1996;6:381-385.

35. Yusuf S, Hawken S, Ounpuu S, Dans T, Avezum A, Lanas F, McQueen M, Budaj A, Pais P, Varigos J, Lisheng L. INTERHEART_Study Investigators: Effect of potentially modifiable risk factors associated with myocardial infarction in 52 countries (the INTERHEART study): A case-control study. Lancet. 2004;364:937-952. 
36. Kosiborod M, Rathore SS, Inzucchi SE, Masoudi FA, Wang $Y$, Havranek EP, Krumholz HM. Admission glucose and mortality in elderly patients hospitalized with acute myocardial infarction: Implications for patients with and without recognized diabetes. Circulation. 2005;111:3078-3086.

37. Gerstein HC, Islam S, Anand S. Dysglycemia and the risk of acute myocardial infarction in multiple ethnic groups: An analysis of 15,780 patients from the INTERHEART study. Diabetol. 2010;12:2509-2517.

38. Paizan MLM, Vilela-Martin JF. Is there an association between periodontitis and hypertension? Curr Cardiol Rev. 2014;10:355-361.

39. Cześnikiewicz-Guzik M. Chronic oral infections as a risk factor of atherosclerosis and arterial hypertension. Czynniki Ryzyka. 2009;3:52. 